\title{
Analisis Penerapan Aplikasi Sistem Keuangan Desa (Siskeudes) dalam Pengelolaan Keuangan Di Desa Banyudono Kecamatan Dukun
}

\author{
Alqi Faizah \\ Universitas Tidar Magelang \\ alqifaizah88@gmail.com

\section{Retnosari} \\ Universitas Tidar Magelang \\ retnosari1808@untidar.ac.id
}

\begin{abstract}
Abstrak
Penelitian ini bertujuan untuk mengetahui gambaran efektivitas dan hambatan atau kendala dari penerapan aplikasi sistem keuangan desa (siskeudes) dalam pengelolaan keuangan di Desa Banyudono Kecamatan Dukun. Penelitian ini menggunakan Pendekatan kualitatif dengan jenis penelitian deskriptif kualitatif. Data yang digunakan berasal dari hasil wawancara pihak Desa Banyudono. Analisis datanya menggunakan reduksi data, penyajian data dan verifikasi data. Hasil penelitian menunjukkan bahwa penerapan aplikasi sistem keuangan desa (siskeudes) di Desa Banyudono Kecamatan Dukun sudah berjalan dengan efektif dan efisien dalam membantu Pemerintah Desa Banyudono dalam mengelola keuangan desa. Prosedur pengelolaan keuangan yang dijalankan meliputi tahap Perencanaan, Pelaksanaan, Penatausahaan, dan Pelaporan/Pertanggungjawaban. Namun dalam pengoperasiannya masih terdapat kendala yang tidak terlalu berpengaruh secara signifikan yaitu adanya sistem yang error disaat sedang digunakan sehingga menghambat proses penginputan data. Sistem keuangan desa sangatlah berpengaruh penting dalam pemerintahan desa dimana dengan sistem pengelolaan keuangan desa yang baik akan tercipta akuntabilitas dan transparansi yang optimal.
\end{abstract}

Kata Kunci Penerapan Sistem Keuangan Desa, Pengelolaan Keuangan Desa, Pemerintah desa

\section{PENDAHULUAN \\ A. Latar Belakang}

Menurut Undang-Undang Nomor 6 Tahun 2014, menjelaskan bahwa Desa adalah kesatuan masyarakat hukum dengan batas daerah yang mempunyai kewenangan untuk menyelenggarakan dan mengatur urusan pemerintahan, kepentingan masyarakat setempat sesuai prakarsa masyarakat, hak asal usul dana atau hak tradisional yang diakui dan dihormati oleh sistem Negara Kesatuan Republik Indonesia. Desa dalam mengelola pemerintahannya dipimpin oleh Kepala Desa, dengan salah satu kekuasaannya adalah memegang pengelolaan 
keuangan dan mewakili pemerintah desa dalam kepemilikan kekayaan milik desa. Keuangan desa merupakan segala hak dan kewajiban yang dapat diukur dengan uang dan segala sesuatu berupa uang dan harta kekayaan yang berkaitan dengan pelaksanaan hak dan kewajiban desa. Desa memiliki kebebasan untuk mengatur dan mengelola keuangannya dengan tetap mengikuti aturan dan pedoman yang berlaku. Keuangan desa sendiri dikelola dan diatur dengan menegakkan prinsip akuntabilitas, transparansi, dan dilaksanakan secara tertib dan disiplin anggaran. Setiap desa diberikan kebebasan untuk menyusun laporan keuangan dimana laporan keuangan pemerintah desa disusun untuk menyediakan informasi bagi pemakai informasi. Laporan keuangan tersebut harus memuat informasi yang relevan tentang bagaimana transaksi keuangan ditangani dan semua kegiatan ekonomi dilakukan sehingga dapat menjadi sumber panduan dalam menyusun anggaran periode yang selanjutnya.

Pengelolaan keuangan desa mencakup keseluruhan proses perencanaan, pelaksanaan, penatausahaan, pelaporan, dan pertanggungjawaban keuangan desa. Desa diharuskan mengelola keuangan dengan sebaik baiknya khususnya dalam merencanakan APB Desa yang setiap tahunnya perlu disusun oleh pemerintah desa. Anggaran yang dianggarkan oleh pemerintah desa harus tepat sasaran untuk keperluan kesejahteraan masyarakatnya dan diperlukan adanya laporan atas penggunaan anggaran tersebut agar tercipta akuntabilitas dan transparansi penggunaan dana. Dalam hal ini pemerintah desa diwajibkan membuat laporan pertanggungjawaban atas penggunaan anggaran atau dana yang telah dilakukan, khususnya berupa Laporan Realisasi Pelaksanaan APB Desa dan Laporan Pertanggungjawaban Realisasi Pelaksanaan APB Desa. Laporan pertanggungjawaban ini dihasilkan melalui proses pengelolaan keuangan desa, mulai dari tahap perencanaan dan penganggaran, pelaksanaan dan operasional sampai tahap pertanggungjawaban pengelolaan dan pelaporan keuangan.

Untuk membantu pemerintah desa dalam mengelola keuangan desa, Badan Pengawas Keuangan dan Pembangunan (BPKP) bekerjasama dengan Kementerian Dalam Negeri (Kemendagri) mengembangkan sebuah aplikasi yang dapat mempermudah pemerintahan desa dalam pengelolaan keuangan desa. Aplikasi yang dirancang adalah Aplikasi Sistem Keuangan Desa (Siskeudes) yang diterapkan sejak tahun 2015 dengan dukungan oleh Surat Menteri Dalam Negeri 143/8350/BPD tanggal 27 November 2015 tentang Aplikasi Pengelolaan Keuangan Desa dan Surat KPK Nomor B.7508/01-16/08/2016 tanggal 31 Agustus 2016 tentang Himbauan Terkait Pengelolaan Keuangan Desa/Dana Desa. Aplikasi ini juga mengacu pada Peraturan Menteri Dalam Negeri Nomor 113 Tahun 2014 tentang Pengelolaan Keuangan Desa. Aplikasi Sistem Keuangan Desa (Siskeudes) diharapkan dapat memudahkan pemerintah desa mengelola keuangan desa secara lebih efektif sehingga dapat meningkatkan tingkat akuntabilitas dan transparansi keuangan desa. Penerapan Aplikasi Sistem Keuangan Desa harus saling menguntungkan antara desa dan pihak BPKP. BPKP dengan membuat aplikasi ini dapat digunakan sebagai sarana pengendalian penggunaan dan pengelolaan keuangan oleh pemerintah desa. Selain itu, aplikasi ini akan membantu pihak desa dalam melakukan entry data ke aplikasi ini dalam rangka mengatur keuangan desa.

Sistem keuangan desa akan memberikan keuntungan bagi pemerintah desa untuk menghasilkan informasi yang lebih relevan dan dapat 
dipertanggungjawabkan kepada pihak yang membutuhkan. Dengan adanya sistem ini akan memudahkan perangkat desa dalam penyusunan program desa dan akan mendukung dalam mewujudkan pemerintahan yang transparan, akuntabel, kredibel dan terpercaya serta akan memudahkan partisipasi masyarakat dalam pengelolaan sistem keuangan desa yang membutuhkan perhatian khusus (Ridwan, 2019). Untuk itu dengan adanya sistem ini diharapkan pemerintah desa khususnya Pemerintah Desa Banyudono dapat menggunakan aplikasi ini dengan baik sehingga tercipta pengelolaan keuangan desa yang efektif.

\section{B. Tujuan Penelitian}

Tujuan dari penelitian ini adalah untuk mengetahui efektivitas serta hambatan atau kendala penerapan aplikasi sistem keuangan desa (Siskeudes) dalam pengelolaan keuangan di Desa Banyudono Kecamatan Dukun.

\section{Manfaat Penelitian}

1. Bagi Peneliti, memberikan tambahan informasi mengenai bagaimana penerapan aplikasi sistem keuangan desa (siskeudes) yang dapat memudahkan proses pengelolaan keuangan desa.

2. Bagi Pemerintah Desa Banyudono, memberikan masukan dan saran mengenai bagaimana penerapan aplikasi sistem keuangan desa yang tepat sesuai dengan standar yang ada.

3. Bagi Pembaca, memberikan pengetahuan yang dapat dipelajari dan dapat dijadikan sebagai referensi penelitian yang sejenis.

\section{Rumusan Masalah}

1. Bagaimana efektivitas penerapan aplikasi sistem keuangan desa (siskeudes) dalam pengelolaan keuangan di Desa Banyudono Kecamatan Dukun?

2. Apa saja hambatan atau kendala dalam penggunaan aplikasi sistem keuangan desa (siskeudes) dalam pengelolaan keuangan di Desa Banyudono Kecamatan Dukun?

\section{LANDASAN TEORI}

\section{A. Pengertian Desa}

Desa adalah kesatuan masyarakat hukum yang berhak mengurus masyarakatnya sendiri berdasarkan hak dan adat istiadat yang diakui oleh pemerintah dan desa tersebut berada di daerah kabupaten. Menurut UndangUndang Nomor 6 Tahun 2014 Pasal 1 menyatakan bahwa, Desa adalah kesatuan masyarakat hukum dengan batas wilayah yang berwenang untuk mengatur dan mengelola urusan pemerintahan, kepentingan masyarakat setempat atas prakarsa masyarakat, hak asal-usul atau hak tradisional yang diakui dan dihormati dalam sistem pemerintahan Negara Kesatuan Republik Indonesia. Dari beberapa pengertian tersebut dapat disimpulkan bahwa Desa adalah kesatuan masyarakat hukum yang bertempat tinggal di suatu daerah yang mempunyai kekuasaan menyelenggarakan dan mengelola kegiatan pemerintahan menurut asal-usulnya dan yang diakui dalam sistem pemerintahan Negara Kesatuan Republik Indonesia.

\section{B. Pemerintahan Desa}

Pemerintah desa menurut Peraturan Pemerintah Nomor 72 tahun 2005 adalah badan yang menyelenggarakan segala urusan Pemerintahan Desa dan 
Badan Permusyawaratan Desa dalam mengatur dan mengelola urusan masyarakat berdasarkan asal-usul dan adat istiadat setempat yang diakui dan dihormati di sistem Pemerintahan Negara Kesatuan Republik Indonesia. Dalam menjalankan pemerintahan desa, desa dipimpin oleh seorang Kepala Desa yang dibantu oleh perangkat desa yang terdiri dari sekertariat desa, pelaksana kewilayahan, dan pelaksana teknis.

Susunan kerja pemerintah desa sesuai dengan Peraturan Menteri Dalam Negeri Nomor 84 Tahun 2015 Tentang Struktur Organisasi dan Tata Kerja (SOT) Pemerintah Desa, antara lain yaitu:

1. Sekretaris desa. Sekertaris desa dalam melaksanakan tugasnya dibantu oleh stafnya. Sekertaris desa memegang urusan dalam bidang tata usaha dan umum, keuangan dan perencanaan, dan paling sedikit dua urusan yaitu urusan umum dan perencanaan serta keuangan.

2. Pengelolaan zona/wilayah. Pengelola kewilayahan membantu kepala desa sebagai satuan tugas kewilayahan. Pengelola ini memiliki tanggungjawab dalam penyelenggaraan pemerintahan desa, pembangunan desa, pembinaan masyarakat desa, dan pemberdayaan masyarakat desa.

3. Pelaksana teknis tugas operasional. Pelaksana teknis membantu tugas seorang Kepala Desa dalam menjalankan tugas operasionalnya.

\section{Pengelolaan Keuangan Desa}

Pengelolaan keuangan desa adalah suatu kegiatan pengelolaan keuangan yang meliputi tahap perencanaan, tahap pelaksanaan, tahap penatausahaan dan tahap pelaporan dalam pemerintahan desa. Pengelolaan keuangan desa dilaksanakan dengan berpedoman pada prinsip transparansi, tanggung jawab, partisipasi dan pelaksanaan anggaran secara tertib dan disiplin. Kepala Desa dalam mengelola keuangan desa memiliki kekuasaan yang sangat penting yaitu sebagai pihak yang memegang kekuasaan dan mewakili pemerintah dalam mengatur kepemilikan kekayaan yang dipisahkan dan mengatur kebijakan pengelolaan keuangan desa. Kepala desa dalam hal ini didukung oleh Pelaksana Teknis Pengelolaan Keuangan Desa (PTPKD), termasuk sekretaris desa dan perangkat desa.

Tahapan dalam pengelolaan keuangan desa meliputi beberapa tahap dibawah ini yaitu :

1. Tahap Perencanaan

Pada tahap ini mencakup tahap penyusunan program atau kegiatan yang akan dilaksanakan pada desa yang bersangkutan. Pada tahap ini pemerintah desa mengadakan musyawarah terlebih dahulu dengan melibatkan masyarakat untuk merumuskan suatu kegiatan atau program kerja dengan menjunjung tinggi aspirasi masyarakat dan skala prioritas pembangunan.

\section{Tahap Pelaksanaan}

Pada tahap ini, program atau kegiatan yang telah dirumuskan sebelumnya akan diimplementasikan dalam suatu kegiatan. Pelaksanaan keuangan desa sendiri merupakan kegiatan dari proses perencanaan yang sudah dirumuskan kemudian dilakukanlah pembangunan desa. Pelaksanaan ini hendaknya dilakukan dengan baik dan sesuai dengan anggaran yang telah ditetapkan bersama untuk kesejahteraan masyarakat.

3. Tahap Penatausahaan 
Pada tahap ini, semua kegiatan yang telah dilakukan atau direalisasikan akan dikelompokkan atau disusun dengan baik sesuai transaksi agar dapat dilaporkan. Penatausahaan keuangan desa merupakan suatu kegiatan yang di dalamnya terdapat proses penatausahan dalam proses pembangunan desa.

4. Tahap Pelaporan

Pada tahap ini akan dihasilkan sebuah laporan atas pelaksanaan kegiatan yang telah dilakukan sehingga akan dapat dipertanggungjawabkan kepada pihak yang berkepentingan. Tahapan ini akan menghasilkan laporan keuangan yang akan diberikan kepada pemangku kepentingan atau pihak yang memerlukan informasi.

\section{Sistem Keungan Desa (Siskeudes)}

Sistem Keuangan Desa (Siskeudes) merupakan aplikasi yang dapat digunakan untuk membantu pemerintah desa mengelola keuangan desa mulai dari tahap perencanaan hingga tahap pelaporan atau pertanggungjawaban. Siskeudes dibuat oleh BPKP untuk membantu pemerintah desa mengelola keuangan desa. Aplikasi ini menyediakan fitur-fitur yang dapat dengan mudah digunakan oleh operator untuk menjalankan aplikasi ini dengan baik sehingga dapat bermanfaat. Proses penginputan yang dilakukan disesuaikan dengan bukti transaksi sehingga dihasilkan output berupa dokumen administrasi dan laporan keuangan yang diperlukan untuk pelaporan atau pertanggungjawaban atas penggunaan dana yang telah dianggarkan sebelumnya.

Tata cara penggunaan aplikasi Siskeudes dilakukan dengan permohonan penggunaan aplikasi Siskeudes dari Pemerintah Daerah kepada Kementerian Dalam Negeri atau perwakilan BPKP setempat dengan tujuan agar penggunaan aplikasi Siskeudes dapat diatur oleh Pemerintah Daerah sehingga dapat diterapkan pada seluruh desa di wilayah pemerintahan daerah yang bersangkutan. Persetujuan penggunaan aplikasi Siskeudes dilakukan dengan memberikan kode SML Pemda yang dikeluarkan secara resmi oleh BPKP dan Kementerian Dalam Negeri (BPKP, 2018).

\section{METODE PENELITIAN}

\section{A. Jenis Penelitian}

Penelitian ini menggunakan jenis penelitian deskriptif kualitatif dengan mengolah data kualitatif yang diperoleh dari proses wawancara dan dokumentasi di kantor Desa Banyudono, yang berisi tentang penjelasan dan gambaran penerapan aplikasi sistem keuangan desa (siskeudes) dalam pengelolaan keuangan desa.

\section{B. Lokasi Penelitian}

Lokasi penelitian adalah tempat dimana dilakukannya penelitian. Penelitian ini dilakukan di Kantor Desa Banyudono di Jalan Muntilan Talun KM 5 Kecamatan Dukun, Kabupaten Magelang.

\section{Sumber Data}

Sumber data yang digunakan peneliti dalam penelitian ini adalah data primer dan data sekunder. Data primer diperoleh dari wawancara langsung dan dokumentasi dengan Pemerintah Desa Banyudono tentang aplikasi sistem 
keuangan desa (siskeudes). Sedangkan untuk data sekunder diperoleh dari dokumen, studi kepustakaan atau arsip terkait.

\section{Teknik Pengumpulan Data}

Ada beberapa teknik pengumpulan data yang digunakan peneliti dalam mengumpulkan data penelitian yaitu sebagai berikut :

1. Wawancara

Wawancara digunakan dalam mengumpulkan data untuk mengungkap masalah bahkan ketika peneliti ingin mengetahui lebih banyak tentang responden (Sugiyono, 2016).

\section{Observasi}

Observasi dilakukan guna untuk mengetahui secara langsung dan tidak langsung terkait penerapan aplikasi siskeudes dalam pengelolaan keuangan di Desa Banyudono.

3. Dokumentasi

Dokumentasi adalah suatu teknik yang digunakan untuk mendapatkan sebuah data yang berbentuk gambar, catatan dan sebagainya yang digunakan untuk mendukung penelitian.

\section{E. Analisis Data}

Analisis data yang dilakukan oleh peneliti meliputi beberapa langkah dibawah ini yaitu sebagai berikut :

1. Reduksi data

Reduksi data dilakukan oleh peneliti dengan cara mencari faktor-faktor yang diangggap penting dari hasil penelitian dengan cara meringkas dan mengkategorikan masalah yang ada sehingga peneliti dapat memahami data yang dikumpulkan di lokasi penelitian.

2. Penyajian data

Penyajian data akan memberikan gambaran mengenai keseluruhan hasil penelitian yang disusun secara ringkas, padat, jelas dan rinci untuk memudahkan peneliti memahami kerangka umum atau bagian khusus penelitian.

3. Kesimpulan

Kesimpulan adalah langkah terakhir dalam proses analisis data. Pada kesimpulan ini, peneliti akan mengetahui hasil akhir dari penelitian yang dilakukan.

\section{HASIL DAN PEMBAHASAN}

\section{A. Gambaran Umum Desa Banyudono}

Desa Banyudono merupakan salah satu desa yang terletak di wilayah Kecamatan Dukun, Kabupaten Magelang. Desa Banyudono terdiri dari 15 Dusun yang ada di dalamnya yaitu Dusun Demo, Dusun Gejayan, Dusun Kwadasan, Dusun Banjengan, Dusun Setran, Dusun Macanan, Dusun Klatak, Dusun Selo Bentar, Dusun Selo Merah, Dusun Selo Iring, Dusun Selo Bendo, Dusun Karang, Dusun Surobandan, Dusun Talun Kidul, dan Dusun Talun Lor. Luas wilayah Desa Banyudono kurang lebih seluas 493,947 Ha. Desa Banyudono memiliki jumlah penduduk sebanyak 5355 jiwa yang mata pencaharian penduduknya rata rata bekerja sebagai petani. 


\section{B. Hasil Pembahasan Penelitian}

Pada awalnya aplikasi Sistem Keuangan Desa (Siskeudes) dikembangkan oleh Badan Pengawasan Keuangan dan Pembangunan (BPKP) dan Kementerian Dalam Negeri (Kemendagri). Aplikasi ini dibuat dengan harapan agar pemerintah desa dapat menjalankan pengelolaan keuangan desa dengan memanfaatkan kecanggihan teknologi dan dapat menghasilkan proses yang efektif dan efisien dalam mengelola keuangan desa. Sejak tahun 2015 Aplikasi Sistem Keuangan Desa (Siskeudes) telah diterapkan sesuai dengan Surat Menteri Dalam Negeri No. 143/8350/BPD tanggal 27 November 2015 tentang Aplikasi Pengelolaan Keuangan Desa dan Surat KPK No. B.7508/01-16/08/2016 tanggal 31 Agustus 2016 tentang Himbauan terkait Pengelolaan Keuangan Desa/Dana Desa. Aplikasi ini berkaitan dengan peraturan pengelolaan keuangan desa yang berlaku saat itu yaitu Permendagri No. 113 Tahun 2014 tentang pengelolaan keuangan desa. Kementerian Dalam Negeri menerbitkan Permendagri No. 20 Tahun 2018 tentang Pengelolaan Keuangan Desa, untuk menggantikan Permendagri No. 113 Tahun 2014, sehingga diperlukan penyesuaian dengan regulasi terbaru tersebut. Aplikasi Siskeudes terbaru dikeluarkan dengan versi 2.0. Tampilan muka aplikasi siskeudes versi 2.0 yang sesuai dengan Permendagri Nomor 20 Tahun 2018 adalah sebagai berikut :

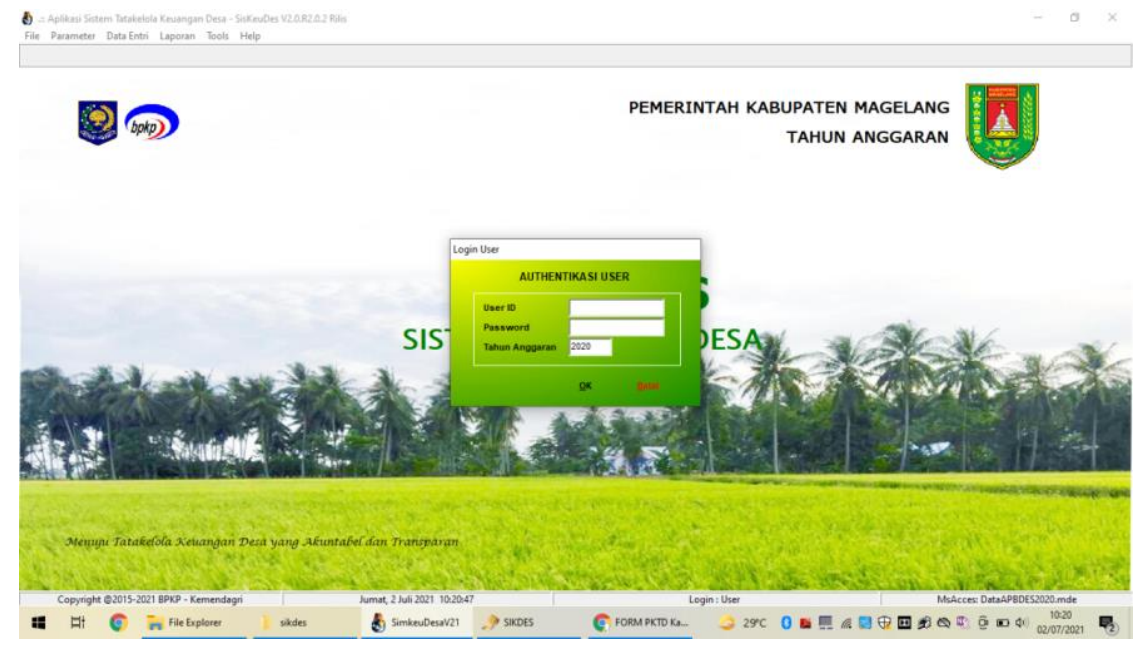

Gambar 1. Tampilan Antar Muka

C. Efektivitas Penerapan Aplikasi Sistem Keuanngan Desa (Siskeudes) dalam Pengelolaan Keuangan di Desa Banyudono

Aplikasi Sistem Keuangan Desa (Siskeudes) merupakan suatu aplikasi yang ditujukan kepada pemerintah desa agar digunakan untuk membantu mempermudah dalam pengelolaan keuangan desa mulai dari tahap perencanaan sampai tahap paling akhir yaitu pelaporan atau pertanggungjawaban. Aplikasi ini dibuat dengan beberapa pertimbangan sehingga dapat dijadikan sebagai sistem yang dapat mempermudah pengelolaan keuangan desa.

Dari penelitian yang telah dilakukan dapat diketahui bahwa di Desa Banyudono telah menerapkan aplikasi ini mulai tahun 2018 dengan dilakukan bimbingan dan pelatihan terlebih dahulu agar operator yang ditunjuk dapat menjalankan atau mengoperasikan aplikasi ini secara terstruktur dan sesuai dengan prosedur yang ada. Pengggunaan aplikasi siskeudes di Desa Banyudono 
sampai saat ini sudah cukup efektif untuk membantu dalam proses pengelolaaan keuangan desa yang dapat dilihat dari output penggunaan aplikasi ini yaitu dalam proses pelaporan. Dalam proses pelaporan ini, laporan pertanggungjawaban program atau kegiatan dapat dibuat atau dilaporkan secara tepat waktu dengan laporan yang sesuai dengan aturan yang ada.

Dari hasil pengamatan yang telah dilakukan di kantor Desa Banyudono, didapatkan hasil bahwa pengelolaan keuangan desa dengan aplikasi siskeudes dapat dibagi menjadi beberapa tahapan penginputan yaitu:

1. Tahap Perencanaan

Tahap perencanaan dimulai dari proses penetapan tujuan organisasi, penentuan strategi untuk mencapai tujuan organisasi tersebut secara menyeluruh, perumusan sistem perencanaan yang menyeluruh untuk mengintegrasikan dan mengoordinasikan seluruh pekerjaan organisasi, hingga pencapaian tujuan organisasi (Bastian, 2015). Perencanaan akan dilakukan oleh pemerintah desa bersama dengan masyarakat setempat melalui musyawarah desa agar dapat menampung aspirasi masyarakat dengan baik sehingga dapat merencanakan kegiatan yang sesuai dengan apa yang dibutuhkan oleh masyarakat. Pemerintah desa dalam merencanakan suatu program atau kegiatan harus memerhatikan skala prioritas pembangunan desa karena dengan berfokus pada skala tersebut pemerintah desa dapat melaksanakan pembangunan yang merata bagi masyarakatnya.

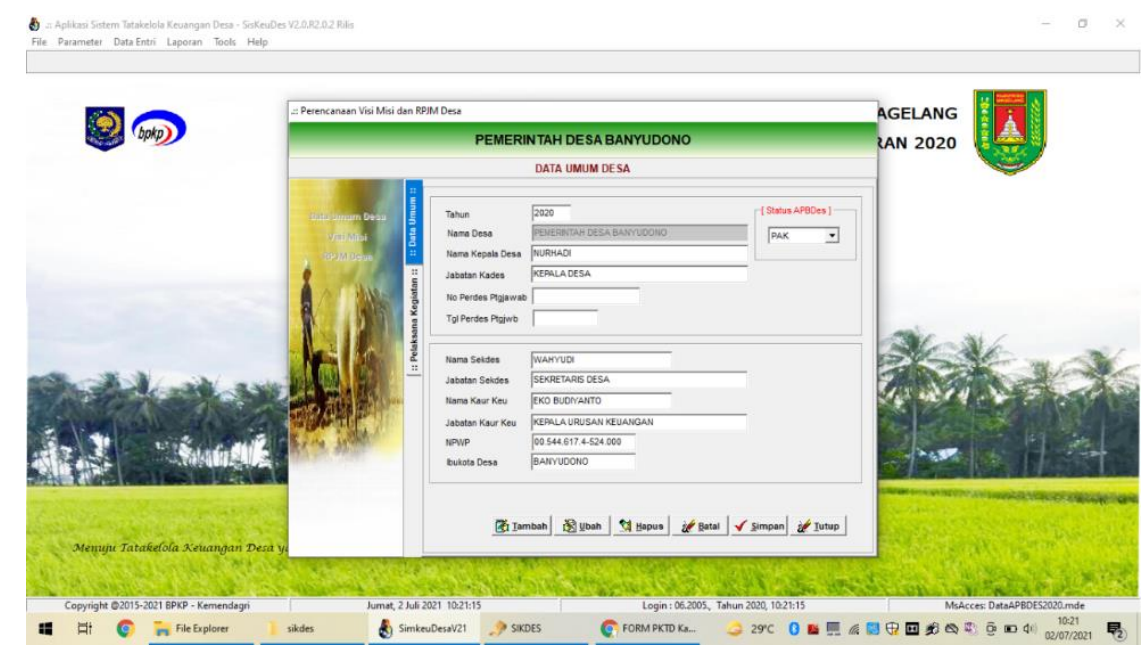

Gambar 2. Parameter Perencanaan

Perencanaan pembangunan desa disusun secara berjangka dan ditetapkan dengan Peraturan Desa yang meliputi Rencana Pembangunan Jangka Menengah Desa (RPJM Desa) untuk jangka waktu enam tahun dan Rencana Pembangunan Tahunan Desa (RKP Desa) dengan jangka waktu satu tahun. RPJM Desa maupun RKP Desa disusun berdasarkan hasil kesepakatan dalam musyawarah desa yang pelaksanaannya paling lambat pada bulan Juni tahun anggaran belanja (BPKP, 2016).

Berdasarkan hasil wawancara dengan pihak desa peneliti memperoleh informasi bahwa dalam penginputan di tahap perencanaan ini Pemerintah Desa Banyudono sudah melakukan musyawarah desa dengan beberapa pihak yang 
berkepentingan terlebih dahulu melalui Musrenbag desa guna mendengarkan aspirasi masyarakat terkait usulan program yang diajukan oleh masyarakat. Setelah dilakukan musyawarah, maka pemerintah desa akan mereview RPJMDesa bersama tim RKP apabila sudah baik akan dituangkan menjadi RKPDesa setelah itu akan dilakukan penginputan kedalam aplikasi siskeudes mengenai apa saja program yang akan direncanakan dan dianggarkan.

\section{Tahap Penganggaran}

Proses penganggaran akan dilakukan apabila RKP desa sudah ditetapkan. Pada tahap ini akan dilakukan proses penyusunan APB Desa yang disesuaikan dengan RKP desa. APB Desa merupakan suatu anggaran yang mencakup rencana keuangan tahunan pemerintah desa dimana mencakup program atau kegiatan yang akan dilaksanakan sesuai dengan kewenangan desa. Penganggaran pengeluaran harus didukung dengan adanya kepastian tersedianya penerimaan dalam jumlah cukup dan harus didukung dengan dasar hukum yang melandasinya (BPKP, 2016).

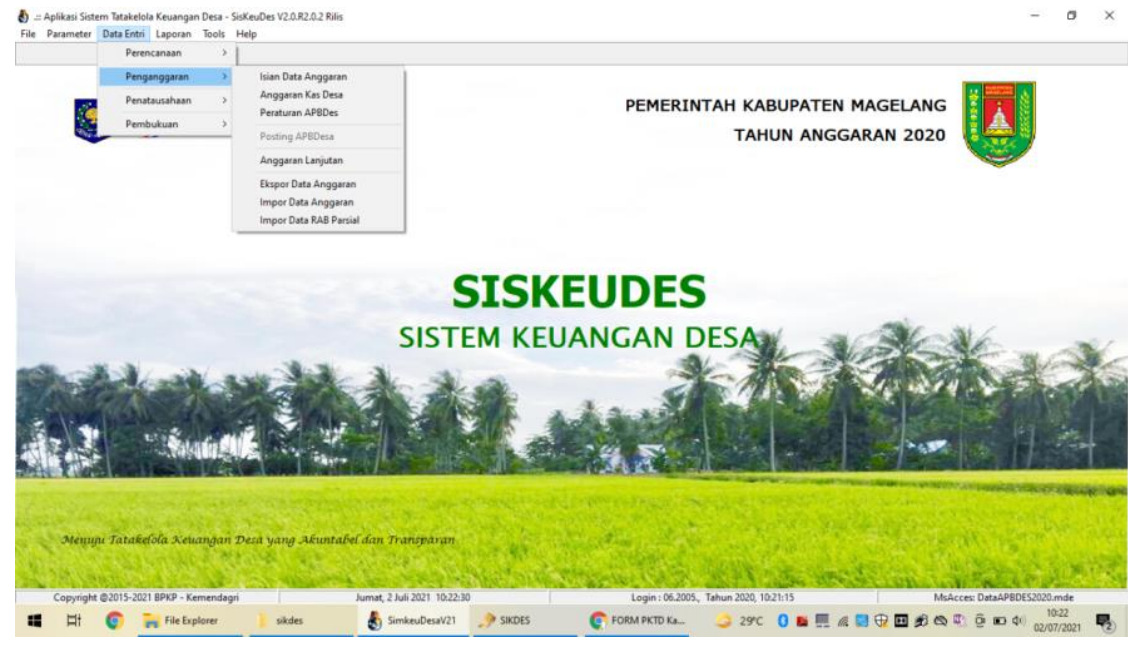

Gambar 3. Parameter Penganggaran

Berdasarkan hasil wawancara yang telah dilakukan oleh peneliti, dalam proses penganggaran ini akan dilakukan penginputan ke aplikasi siskeudes apabila Peraturan Desa terkait APBDesa telah ditetapkan. Pada tahap penganggaran ini, operator akan memasukkan data sesuai dengan apa yang akan dianggarkan dalam rencana program kerja yang sudah disetujui. Proses penginputan dalam tahap penganggaran ini tidak dilakukan secara manual tetapi oleh operator langsung dilakukan penginputan langsung di aplikasi siskeudes sesuai dengan dokumen yang akan diinput. Dalam hal ini operator di Desa Banyudono sudah paham terkait dengan bagaimana mengoperasikan aplikasi. Oleh karena itu, dapat diketahui bahwa operator yang melakukan penginputan aplikasi ini sudah paham akan teknis pengoperasian aplikasi siskeudes khususnya pada tahap penganggaran.

3. Tahap Penatausahaan

Penatausahaan keuangan desa dilakukan oleh Bendahara Desa dan pelaksana kegiatan dengan menggunakan formulir/dokumen/buku. Bendahara 
Desa mempunyai kewajiban dalam melakukan pencatatan terhadap seluruh transaksi yang ada berupa penerimaan dan pengeluaran serta melakukan pencatatan secara sistematis dan kronologis atas transaksi-transaksi keuangan yang terjadi ke dalam aplikasi siskeudes.

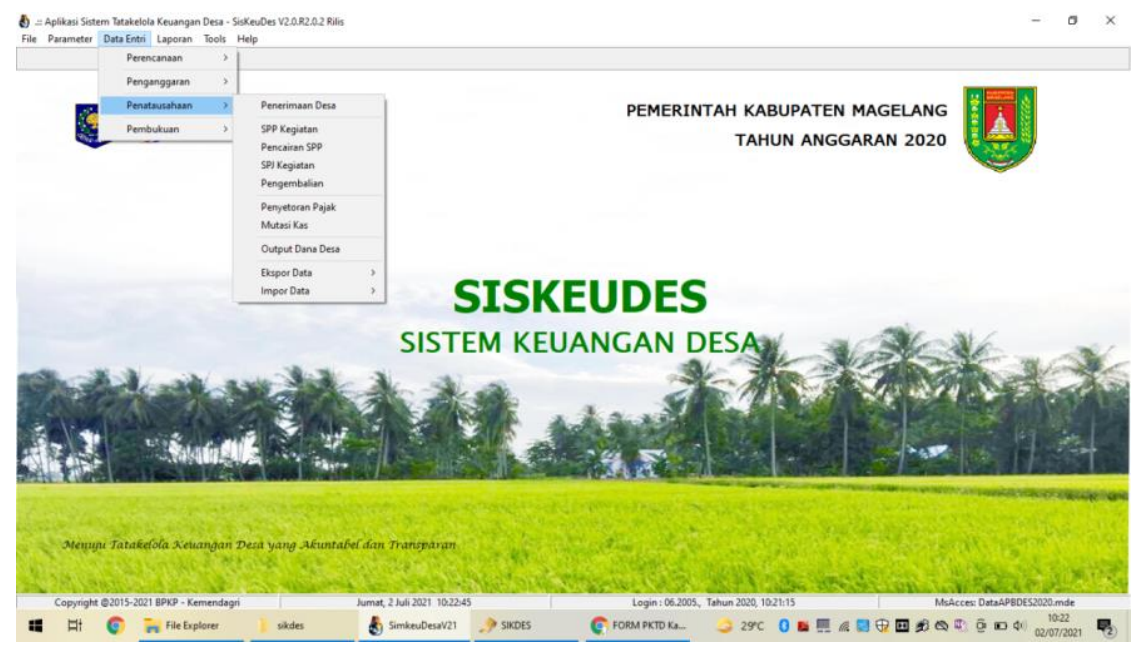

Gambar 4. Parameter Penatausahaan

Berdasarkan hasil wawancara yang telah dilakukan oleh peneliti, dapat diketahui bahwa pada tahap penatausahaan ini sudah dilakukan dengan baik namun masih terdapat kendala dalam penginputan setiap transaksinya. Dalam melakukan penginputan pada tahap ini, dibutuhkan ketelitian karena setiap data yang diinput harus sesuai untuk setiap bidangnya seperti belanja pemerintahan desa, pembangunan, pemberdayaan dan lain sebagainya. Jika ada kesalahan dalam penginputan maka akan berpengaruh terhadap bagian yang lainnya. Oleh karena itu pada tahap ini agak memakan waktu yang lama dan ketelitian dalam penginputan data ke aplikasi siskeudes

4. Tahap Pelaporan atau Pertanggungjawaban

Pada tahap pelaporan ini, akan dihasilkan laporan keuangan yang dapat digunakan sebagai bentuk pertanggungjawaban atas program kerja yang telah dilaksanakan atau anggaran yang telah direalisasikan contohnya dalam hal pembangunan. Tahap ini akan menghasilkan laporan pertanggungjawaban apabila setiap tahapan dapat dilalui dengan baik dan benar, namun jika terdapat kesalahan dari salah satu tahap diatas maka laporan pertanggungjawaban tidak akan muncul di sistem ini. Oleh karena itu dibutuhkan ketelitian dan fokus pada saat melakukan penginputan data atau pengolahan data dari tahap perencanaan sampai pada tahap pelaporan atau pertanggungjawaban ini. Laporan keuangan yang dihasilkan dari proses pengelolaan keuangan desa akan digunakan sebagai sumber pelaporan atas anggaran yang telah dianggarkan sebelumnya sehingga dapat menjunjung prinsip transparansi dan akuntabilitas penggunaan dana. Apabila laporan keuangan sebagai laporan pertanggungjawaban sudah dihasilkan maka Kepala Desa wajib untuk melaporkan kepada pihak yang berkepentingan terhadap informasi yang termuat dalam laporan pertanggungjawaban secara terbuka. 


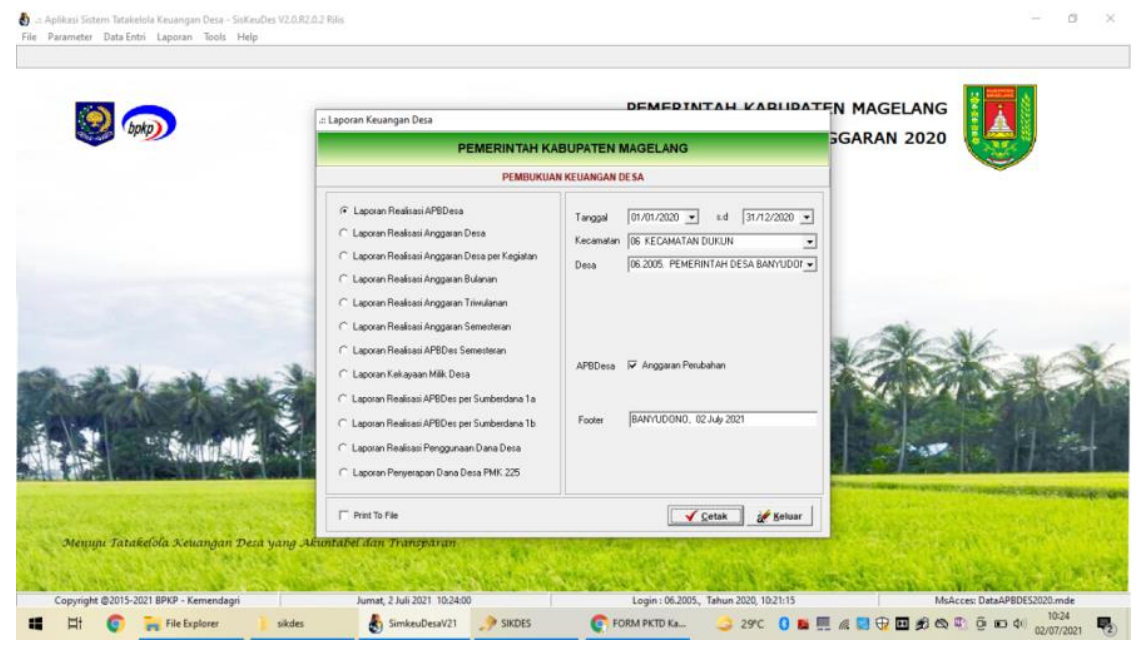

Gambar 5. Parameter Pelaporan

Berdasarkan hasil wawancara yang telah dilakukan, dapat diambil kesimpulan bahwa penggunaan aplikasi siskuedes sudah cukup efektif karena di Desa Banyudono sendiri semua tahapan sudah dilakukan dengan baik sehingga dapat menghasilkan laporan keuangan yang dapat dipertanggungjawabkan dengan pihak yang membutuhkan. Dengan adanya aplikasi siskeudes ini, Pemerintah Desa Banyudono merasa terbantu karena memudahkan dalam proses pengelolaan keuangan desa sehingga dalam hal pelaporan ini akan dihasilkan laporan keuangan secara otomatis. Jika dari awal tahap perencanaan sudah baik dan sesuai dengan apa yang di input maka dalam hal pelaporan akhir ini akan didapatkan hasil yang baik dan benar. Namun sebaliknya jika masih ada kesalahan di salah satu tahapannya akan memengaruhi tahapan yang lainnya. Oleh karena itu, dalam menggunakan aplikasi siskeudes ini harus dilakukan dengan penuh ketelitian dan kesabaran dalam setiap tahapan penginputannya sehingga akan menghasilkan manfaat bagi pengelolaan keuangan desa khususnya di Desa Banyudono.

\section{Hambatan atau Kendala dalam Penerapan Aplikasi Sistem Keuangan Desa di Desa Banyudono}

Aplikasi Siskeudes adalah suatu aplikasi yang mendorong penggunaan teknologi di bidang pengelolaan keuangan desa. Aplikasi ini akan memberikan kemudahan bagi pemerintah desa dalam mengelola keuangan desanya sehingga akan tersistem dengan baik, efektif, dan efisien. Dalam penerapannya, Aplikasi Siskeudes sudah digunakan dengan cukup baik dan cukup efektif dalam membantu Pemerintah Desa Banyudono dalam melakukan pengelolaan keuangan desa yang dilakukan secara online, namun tidak menutup kemungkinan bahwa pada tahapan pengelolaan keuangan desa tetap akan menggunakan sistem offline juga. Di dalam penggunaan aplikasi ini, Pemerintah Desa Banyudono sendiri sudah menerapkannya dengan baik dan Pemerintah Desa Banyudono merasa terbantu dalam hal pengelolaan keuangan desa sehingga dapat dilakukan dengan mudah. Dalam menjalankan aplikasi Sistem Keuangan Desa (Siskeudes) ini, operator Desa Banyudono sudah mempunyai kemampuan yang baik dalam mengelola setiap tahapan dalam penginputan data. 
Namun ada beberapa kendala atau hambatan yang terjadi pada saat proses penginputan data ke dalam aplikasi siskeudes yaitu adanya sistem yang error pada saat penginputan yang agak mengganggu dalam proses penginputan data. Oleh karena itu, cara untuk meminimalisir adanya gangguan sistem yang error yaitu dengan cara mencari tahu informasi kepada pihak yang terkait seperti pihak pendamping desa yang pernah memberikan pelatihan. Kemudian, selain adanya sistem yang error, dalam aplikasi ini terdapat satu tahapan yang agak sulit yaitu di bagian penatausahaan karena dibutuhkan ketelitian dalam menyesuaikan data di buku bank atau buku rekening bank. Jika terdapat kesalahan dalam penginputan di tahap penatausahaan maka akan memengaruhi tahapan proses yang lainnya. Jadi, penginputan dari tahap satu ke tahap lain saling memengaruhi satu sama lain sehingga membutuhkan waktu yang agak lama khususnya di tahap penatausahaan. Oleh karena itu, dibutuhkan sumber daya manusia yang lebih berkompeten dibidangnya untuk meminimalisir kesalahan dalam penginputan. Dalam hal ini, operator desa yang ditunjuk sebagai pengolah aplikasi siskeudes ini harus lebih berpengalaman, berkompeten dan ahli dibidangnya.

\section{PENUTUP}

\section{A. Kesimpulan}

Berdasarkan penelitian yang telah dilaksanakan, dapat diambil kesimpulan sebagai berikut :

1. Penerapan Aplikasi Sistem Keuangan Desa di Desa Banyudono sudah dapat dikatakan cukup efektif dan berjalan dengan baik karena dijalankan sesuai dengan prosedur pengelolaan keuangan desa yaitu Perencanaan, Pelaksanaan, Penatausahaan, dan Pelaporan/pertanggungjawaban.

2. Untuk SDM atau operator pengguna aplikasi siskeudes di Desa Banyudono sudah dapat dikatakan cukup siap dari segi SDM yang terpenuhi walaupun operator mempunyai latar belakang pendidikan SMA.

3. Keuntungan dari penggunaan aplikasi ini adalah Pemerintah Desa Banyudono merasa terbantu dalam melakukan pengelolaan keuangan desa berbasis teknologi sehingga memberikan kemudahan dalam hal pelaporan secara tepat waktu dan pekerjaan akan menjadi lebih efektif dan efisien serta dapat mewujudkan prinsip akuntabilitas dan transparansi penggunaan dana.

4. Kendala atau hambatan yang dihadapi dalam penerapan aplikasi Sistem Keuangan Desa ini adalah adanya sistem yang error pada saat dilakukannya penginputan sehingga menghambat proses tersebut. Selain itu, dari beberapa tahapan pengelolaan keuangan desa tersebut ada satu tahapan yang cukup memakan waktu yang lama dalam proses penginputan data yaitu pada tahap penatausahaan. Dimana tahapan tersebut diperlukan ketelitian yang lebih untuk menghindari kesalahan dalam penginputan data.

\section{B. Saran}

Berdasarkan penelitian yang telah dilakukan sebelumnya, maka saran yang dapat diberikan yaitu :

1. Pemerintah Desa Banyudono diharapkan dapat mempertahankan kinerja yang baik dalam proses pengelolaan keuangan desa yang berbasis aplikasi Sistem Keuangan Desa (Siskeudes) dan memberikan pelatihan tambahan bagi para pegawai yang tidak mengikuti pelatihan agar semua pegawai paham dan 
mampu mengoperasikan aplikasi ini serta untuk mencapai tujuan desa. Namun, tetap hanya satu pegawai yang ditunjuk sebagai operator.

2. Pemerintah Desa Banyudono diharapkan dapat mempertahankan kualitas Sumber Daya Manusia (SDM) agar dapat mendukung proses pengelolaan keuangan desa agar lebih optimal dalam pelaksanaannya.

3. Pemerintah Desa Banyudono dapat lebih sering berkomunikasi kepada pemerintah setempat atau pendamping desa apabila terjadi error pada aplikasi sehingga dapat diminimalisir dengan baik kendala tersebut.

\section{UCAPAN TERIMA KASIH}

Dalam penyusunan artikel ini, penulis mengucapkan terima kasih kepada : (1) Allah SWT yang telah memberikan rahmat dan hidayah-Nya sehingga penulis dapat menyelesaikan penulisan artikel ini, (2) Pegawai Kantor Desa Banyudono Kecamatan Dukun, yang telah memberikan kesempatan kepada penulis untuk melakukan penelitian dan memperoleh informasi yang dibutuhkan dalam penyusunan artikel ini, (3) Keluarga dan teman-teman yang telah memberikan dukungan kepada penulis untuk menyelesaikan artikel ini.

\section{DAFTAR PUSTAKA}

Ayu, G., Wahyuni, A., Kurniawan, S. (2017). Penerapan Sistem Keuangan Desa (SISKEUDES) Terhadap Kinerja Pemerintah desa (Studi Kasus di Desa Kaba-kaba, Kecamatan Kediri, Kabupaten Tabanan). e-Journal S1 Ak. Volume 8, No. 2, 2017.

Basori, A., Megantoro, R., Lasantu, A. (2016). Buku Kerja Aplikasi Sistem Keuangan Desa (SISKEUDES). Bogor : Pusdiklatwas BPKP.

Bastian, Indra. (2015). Akuntansi Untuk Kecamatan dan Desa. Erlangga. Jakarta.

Indrianti, R., Herman, M., \& Fibriyanita, F. (2020). Efektivitas Penerapan Aplikasi Sistem Keuangan Desa (Siskeudes) dalam Pengelolaan Keuangan di Desa Kertak Empat Kecamatan Pengaron. Universitas Islam Kalimantan.

Mahalika, J., Karomay, H., Pusung, R. (2018). Penerapan Sistem Keuangan Desa ( SISKEUDES) Pada Organisasi Pemerintah desa (Studi Kasus di Desa Suwaan Kecamatan Kalawat Kabupaten Minahasa Utara). Jurnal Riset Akuntansi. Volume 13, No. 4, 2018. Page 578-583.

Novianto, M., Hantoro. (2013). Perubahan Status Desa Menjadi Kelurahan dalam Sistem Ketatanegaraan. Kajian. Volume 18, No. 4, Desember 2013, Page 237-254.

Peraturan Menteri Dalam Negeri Nomor 20 Tahun 2018 Tentang Pengelolaan Keuangan Desa.

Peraturan Menteri Dalam Negeri Nomor 84 Tahun 2015 Tentang Susunan Organisasi dan Tata Kerja (SOT). 
Peraturan Menteri Dalam Negeri Republik Indonesia Nomor 113 Tahun 2014 Tentang Pengelolaan Keuangan Desa.

Puspawijaya, A., Siregar, J. (2016). Pengelolaan Keuangan Desa. Bogor : Pusdiklatwas BPKP.

Ridwan, M., (2019). Analisis Peran Aplikasi Sistem Keuangan Desa (SISKEUDES) dalam Meningkatkan Kualitas Akuntabilitas Keuangan Desa Ditinjau dari Prespektif Ekonomi Islam. Skripsi. Universitas Islam Negeri Raden Intan Lampung. September 2019.

Rivan, A., Maksum, I. (2019). Penerapan Sistem Keuangan Desa dalam Pengelolaan Keuangan Desa. Jurnal Administrasi Publik. Volume 9, No. 2, Desember 2019. Page $92-$ 100. http://dx.doi.org/10.31289/jap.v9i2.2487

Sucahyo, H. (2019). Pengelolaan APBDes dengan Sistem Keuangan Desa di Kabupaten Malang Jawa Timur. Jurnal Karta Raharja. Volume 1, No. 1, Juli 2019, Page 33-36. http://ejurnal.malangkab.go.id/index.php/kr

Sugiman. (2018). Pemerintah desa. Jurnal Binamulia Hukum. Volume 7, No. 1, Juli 2018. Page 82-95.

Sugiyono. (2016). Metode Penelitian Kuantitatif, Kualitatif, dan R\&D. Bandung: Alfabeta.

Undang-Undang Republik Indonesia Nomor 6 Tahun 2014 Tentang Desa.

Wibow, H., Triyanto, D., Sutojo, A. (2020). Implementasi Aplikasi Sistem Keuangan Desa (SISKEUDES) 2.0 Di Desa Guru Agung 1 Kecematan Kaur Utara Kabupaten Kaur. Journal of Social Politics and Governance. Volume 2, No. 2, Desember 2020. Page 152 